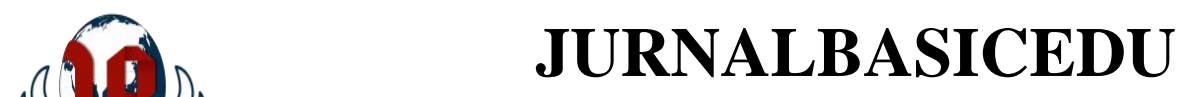

Volume 5 Nomor 5Tahun 2021 Halaman 3142 - 3149

Research \&Learningin Elementary Education https://jbasic.org/index.php/basicedu

PAHLAWAN

\title{
Pengaruh Penerapan Metode SAS (Struktural Analitik Sintetik) terhadap Kemampuan Membaca Permulaan Siswa di Sekolah Dasar
}

\author{
Afifatus Silfiyah $^{1 \bowtie}$, Syamsul Ghufron ${ }^{2}$, Muslimin Ibrahim $^{3}$, Pance Mariati ${ }^{4}$ \\ Universitas Nahdlatul Ulama Surabaya, Indonesia ${ }^{1,2,3,4}$ \\ E-mail: afifatussilfiyah080.sd17@ student.unusa.ac.id ${ }^{1}$, syamsulghufron@ unusa.ac.id ${ }^{2}$, \\ muslimin.ibr@gmail.com ${ }^{3}$, pance_mariati@unusa.ac.id ${ }^{4}$
}

\begin{abstract}
Abstrak
Latar belakang penelitian ini dengan adanya permasalahan di UPT SD Negeri 266 Gresik yang mengalami pengaruh penerapan metode SAS terhadap kemampuan membaca permulaan. Pengaruh metode SAS terhadap kemampuan membaca permulaan di UPT SD Negeri 266 Gresik dikarenakan kurangnya motivasi kepada siswa untuk membaca dan kurangnya metode yang digunakan dan ada beberapa faktor lain yang dapat mempengaruhi minat belajar membaca terhadap siswa.Tujuan penelitian ini untuk mengetahui pengaruh metode SAS terhadap kemampuan membaca permulaan siswa. Penelitian ini merupakan jenis penelitian kuantitatif yang menggunakan metode One-Group Pretest-Posttest Design. Teknik pengambilan data menggunakan teknik wawancara, observasi, dokumentasi, dan soal tes. Berdasarkan hasil wawancara dan pemberian tes menunjukkan bahwa dari 24 siswa terdapat 23 siswa yang belum bisa membaca dengan lancar. Hasil analisis data menggunakan uji regresi sederhana. Hasil analisis data diperoleh signifikansi sig. $0.947<$ 0,05 yang artinya menunjukkan metode SAS terhadap kemampuan membaca permulaan siswa memberikan pengaruh yang positif dalam meningkatkan kemampuan membaca siswa.
\end{abstract}

Kata Kunci: metode SAS, Kemampuan siswa, membaca permulaan.

Abstract

The background of this research is that there are problems in the UPT SD Negeri 266 Gresik which have the effect of applying the SAS method on early reading skills. The effect of the SAS method on early reading skills at UPT SD Negeri 266 Gresik is due to the lack of motivation for students to read and the lack of methods used and there are several other factors that can affect students' interest in learning to read. The purpose of this study was to determine the effect of the SAS method on reading skills. student start. This research is a type of quantitative research that uses the One-Group Pretest-Posttest Design method. Data collection techniques using interview techniques, observation, documentation, and test questions. Based on the results of interviews and giving tests, it shows that from 24 students there are 23 students who cannot read fluently. The results of data analysis using a simple regression test. The results of data analysis obtained sig significance. 0.947 $<0.05$, which means that the SAS method on students' initial reading ability has a positive influence in improving students' reading skills.

Keywords: SAS method, student's ability, beginning reading.

Copyright (c) 2021 Afifatus Silfiyah, Syamsul Ghufron, Muslimin Ibrahim, Pance Mariati

Corresponding author :

Email : afifatussilfiyah080.sd17@student.unusa.ac.id

DOI : https://doi.org/10.31004/basicedu.v5i5.1321

ISSN 2580-3735 (Media Cetak)

ISSN 2580-1147 (Media Online) 
3143 Pengaruh Penerapan Metode SAS (Struktural Analitik Sintetik) terhadap Kemampuan Membaca Permulaan Siswa di Sekolah Dasar-Afifatus Silfiyah, Syamsul Ghufron, Muslimin Ibrahim, Pance Mariat

DOI: https://doi.org/10.31004/basicedu.v5i5.1321

\section{PENDAHULUAN}

Pendidikan adalah aktivitas dan usaha manusia untuk meningkatkan kepribadiannya dengan jalan membina potensi-potensi pribadinya. Pendidikan yang berkualitas merupakan hal yang paling penting dan merupakan dasar kualitas manusia Indonesia. Pendidikan sekolah dasar merupakan satuan pendidikan dasar yang diperlukan dan harus dilalui setiap anak untuk dapat melanjutkan pendidikannya ke jenjang yang lebih tinggi.

Bekal utama yang perlu dikuasai siswa sekolah dasar adalah pengenalan huruf sebagai kemampuan membaca. Huruf merupakan simbol sekunder bahasa. Bagi anak, kehadiran huruf memiliki makna jika hurufhuruf itu mereka perlukan dalam kehidupan berbahasa. Anak-anak perlu mengenal huruf karena mereka tertarik membaca nama toko, nama jalan, tulisan peringatan, merk, cerita singkat bergambar, judul film anakanak dalam alamat surat. Anak-anak mungkin juga perlu mengenal huruf karena mereka tertarik untuk menulis identitas diri, menulis pesan singkat atau mencatat hal-hal yang mereka sukai. Oleh karena itu, materi membaca dan menulis harus dimulai dari minat dan kebutuhan anak itu (Laely, 2013).

Muhyidin (2019) mengungkapkan bahwa membaca adalah suatu kegiatan interaktif untuk memetik serta memahami arti yang terkandung di dalam bahasa tulis. Semua yang diperoleh dari bacaan itu akan membuat daya pikir semakin berkembang, mempertajam pandangan dan memperluas wawasan seorang anak. Dengan belajar membaca anak akan mudah memperoleh ilmu, membaca bukanlah suatu hal yang harus dipaksakan lagi karena akan timbul kesadaran di diri anak betapa pentingnya membaca, melatih kemampuan berfikir anak dengan membaca dapat pula membantu kemampuan berpikir awal mereka.

Menurut Wahidah (2016), membaca permulaan merupakan tahapan dalam proses pembelajaran siswa sekolah dasar. Membaca permulaan adalah keterampilan bahasa tulis yang bersifat reseptif. Disebut reseptif karena dengan membaca seseorang akan dapat memperoleh informasi, memperoleh ilmu dan memperoleh pengalaman baru. Semua yang diperoleh melalui membaca akan memungkinkan orang tersebut untuk memperkuat keterampilan berpikir, mempertajam pandangan dan memperluas wawasan mereka. oleh karena itu, kegiatan membaca merupakan kegiatan yang sangat diperlukan bagi siapa saja yang ingin maju dan berkembang. Oleh karena itu, pelajaran membaca mempunyai peran penting di sekolah.

Kemampuan membaca yang diperoleh pada membaca permulaan akan sangat berpengaruh terhadap kemampuan membaca lanjut. Sebagai kemampuan yang mendasari kemampuan berikutnya maka kemampuan membaca permulaan benar-benar memerlukan perhatian guru, sebab jika dasar itu tidak kuat maka siswa akan mengalami kesulitan untuk dapat memiliki kemampuan membaca yang memadai. Oleh karena itu, membaca dijadikan sebagai topik penelitian ini. Dari hasil observasi yang dilakukan. ditemukan beberapa permasalahan yang dihadapi seorang guru ketika mengajarkan belajar membaca permulaan. Dimana masih banyaknya siswa yang belum bisa membaca dengan fasih yang tentunya akan menyulitkan siswa dalam mengikuti proses belajar mengajar, melihat metode yang digunakan oleh guru ketika proses pembelajaran membaca kurang sesuai, Metode yang digunakan yaitu metode konvensional yang kurang bermakna bagi siswa. Siswa di perkenalkan dengan huruf abjad dari a sampai z baik itu huruf kapital maupun huruf kecil kemudian mrnghafal huruf-huruf tersebut. Setelah siswa hafal, kemudian menerapkan metode eja dalam membaca kata atau kalimat.

Pembelajaran membaca di sekolah dasar terdiri dari dua bagian yaitu membaca permulaan yang dilaksanakan di kelas I dan II. Melalui membaca permulaan ini, diharapkan peserta didik mampu mengenal huruf, suku kata, kata, kalimat dan mampu membaca dalam berbagai konteks. Sedangkan membaca lanjut dilaksanakan di kelas tinggi atau di kelas III, IV, V dan VI (Marlina, 2014).

Membaca permulaan dilakukan secara bertahap, yaitu pra membaca dan membaca. Pada tahap pra membaca, ajarkan siswa: (1) sikap duduk yang baik saat membaca; (2) cara meletakkan buku di atas meja; (3) 
3144 Pengaruh Penerapan Metode SAS (Struktural Analitik Sintetik) terhadap Kemampuan Membaca Permulaan Siswa di Sekolah Dasar-Afifatus Silfiyah, Syamsul Ghufron, Muslimin Ibrahim, Pance Mariat

DOI: https://doi.org/10.31004/basicedu.v5i5.1321

cara memegang buku; (4) cara membuka dan memutar halaman buku; dan (5) melihat dan memperhatikan tulisan. Pembelajaran membaca permulaan berfokus pada aspek teknis seperti ketepatan menyuarakan tulisan, pengucapan intonasi yang benar, kelancaran dan kejelasan bahasa (Marlina, 2014).

Sunendar (2015), menyampaikan tujuan pembelajaran bagi siswa untuk membaca permulaan sebagai berikut: (a). Mengenali lambang-lambang (simbol-simbol bahasa), (b). Mengenali kata dan kalimat, (c). Menemukan ide pokok dan kata-kata kunci, (d). ceritakan kembali isi bacaan singkat tersebut

Menurut Siregar (2003) bahwa metode pembelajaran merupakan cara mengajar atau cara menyampaikan materi pelajaran kepada siswa yang sedang belajar. Di dalam pembelajaran dan pengajaran seorang guru harus cermat dalam melihat masalah-masalah yang terjadi di kelasnya. Mencermati masalahmasalah yang terjadi di dalam kelas ini sebagai titik tolak seorang guru untuk mencari, menemukan dan menerapkan solusi-solusi atas masalah tersebut dalam upaya meningkatkan mutu pembelajaran dan pengajaran. Menggunakan metode yang benar-benar melibatkan murid selama kegiatan proses pembelajaran berlangsung akan memberi peluang besar terhadap pencapaian tujuan pembelajaran.

Menurut Soekarjo (2004) menyatakan sebuah kelas memiliki kelompok anak yang mempunyai berbagai perilaku yang berbeda, tingkat kecerdasan yang beragam, daya serap yang berbeda, dan sebagainya selalu ada variasinya. Oleh sebab itu diperlukan metode yang sesuai dengan kebutuhan dan karakteristik anak berkesulitan belajar membaca.

Salah satu alternatif metode pembelajaran yang dapat digunakan dalam pembelajaran membaca khususnya membaca permulaan bagi siswa berkesulitan membaca adalah dengan penerapan metode SAS (Struktur Analisik Sintetik). Metode ini dianggap cocok untuk pembelajaran membaca permulaan karena manganut prinsip ilmu bahasa umum dan berdasarkan pengalaman bahasa anak. Teknik pelaksanaan pada metode tersebut yakni keterampilan memilih kartu huruf, kartu kata, dan kartu kata yang disusun menjadi kalimat (Lisnawati \& Muthmainah, 2018). Dalam hal ini akan melibatkan kemampuan visual dan persepsi siswa, sehingga kemampuan membaca permulaan anak nantinya akan meningkat.

Menurut Linda (2014), metode SAS merupakan salah satu metode pembelajaran membaca permulaan yang melalui beberapa tahap yaitu: Struktur menampilkan keseluruhan dan memperlihatkan sebuah kalimat utuh, lalu analitik melakukan proses penguraian, kemudian sintetik melakukan penggabungan kembali ke bentuk semula. Metode SAS sangat cocok untuk siswa kelas bawah karena sudah diujikan sebelumnya. Selain itu, metode ini juga sejalan dengan tahapan perkembangan berpikir anak, sehingga sangat cocok digunakan di kelas bawah. Penerapan metode SAS tidak lepas dari peran pendidik. Karena dirancang oleh pendidik untuk memilih dan menggunakan hasil yang akan diperoleh dari kegiatan yang sedang berlangsung dalam penerapan metode yang digunakan. Namun, setiap metode memiliki kelebihan dan kekurangan.

Menurut Broto (2017), bahwa pengembangan metode SAS (Struktural Analitik Sintetik) dilandasi oleh psikologi gestalt. Inti dari psikologi gestalt adalah totalitas, atau keseluruhan yang lebih berarti dari pada sekedar pengumpulan dari unsur-unsurnya, contoh dari psikologi gestalt misalnya mendengarkan musik, maka yang terdengar di telinga seseorang bukanlah urutan nada-nada akan tetapi satu kesatuan yang menyeluruh, berawal dari yang menyeluruh tersebut seseorang dapat mempelajari nada-nada yang membentuk rangkaian lagu, proses analisis dan sintetis ini adalah proses setiap manusia untuk memenuhi dorongan ingin tahu. Keseluruhan timbul lebih awal dari bagian-bagiannya keseluruhan itu lebih dari pada bagian-bagiannya (Agnesta, 2019).

Kelebihan dari metode ini adalah menuntut siswa untuk mengetahui setiap huruf agar dapat menghafalnya dengan lebih cepat, sedangkan kekurangan dari metode ini adalah mengetahui huruf dan menyusunnya menjadi suku kata yang memakan waktu lama, jika tidak diulang-ulang. terus menerus, mereka akan mudah lupa dengan suara hurufnya. 
3145 Pengaruh Penerapan Metode SAS (Struktural Analitik Sintetik) terhadap Kemampuan Membaca Permulaan Siswa di Sekolah Dasar-Afifatus Silfiyah, Syamsul Ghufron, Muslimin Ibrahim, Pance Mariat

DOI: https://doi.org/10.31004/basicedu.v5i5.1321

Dengan metode SAS, kesulitan di atas dapat diatasi. Metode ini menciptakan suasana pembelajaran yang lebih aktif dan siswa dapat dengan mudah memahami bacaan. Sehingga teknik pembelajaran ini dapat mendorong timbulnya gagasan yang lebih bermutu dan dapat meningkatkan pembelajaran membaca siswa (Lisnawati \& Muthmainah, 2018). Hal ini sejalan dengan hasil penelitian (Ghufron et al., 2020) yang menyatakan bahwa pembelajaran dengan pendekatan PAIKEM (pembelajaran aktif, inovatif, kreatif, efektif, dan menyenangkan) menunjukkan hasil yang menggembirakan baik dari segi aktivitas guru, aktivitas siswa, respons siswa, maupun kompetensi siswa. Berdasarkan analisis di atas peneliti ingin mengangkat permasalahan tersebut, penulis ingin meneliti tentang penerapan metode SAS (struktural analitik sintetik) untuk meningkatkan kemampuan membaca permulaan. Oleh karna itu penulis mengambil judul: "Pengaruh Penerapan Metode SAS (Struktural Analitik Sintetik) Untuk Meningkatkan Kemampuan Membaca Permulaan Siswa Kelas I di UPT SD Negeri 266 Gresik".

\section{METODE PENELITIAN}

Jenis penelitian ini menggunakan penelitian kuantitatif eksperimen dan desain penelitian ini menggunakan one group pretest posttest desain.

Penelitian ini dilaksanakan di UPT SD Negeri 266 Gresik beralamatkan di Jl. Mawa No.32 Raci Tengah Sidayu Gresik. Pengambilan data awal dilakukan dilakukan pada tanggal 13 November 2020 dan penelitian berlangsung pada semester genap tanggan 02 Juni 2021.

Populasi adalah wilayah generalisasi yang terdiri atas objek atau subjek yang mempunyai kualitas dan karakteristik tertentu yang dilakukan peneliti untuk dipelajari dan kemudian dicari kesimpulannya (Sugiyono, 2016). Populasi yang digunakan dalam penelitian ini adalah semua siswa kelas I UPT SD Negeri 266 Gresik yang berjumlah 24 siswa. Pada penelitian ini tidak menggunakan sampel melainkanmenggunakan penelitian populasi dikarenakan subyek penelitian $<100$, sehingga peneliti menggunakan seluruh populasi.

Teknik pengumpulan data data yang digunakan dalam penelitian adalah observasi, wawancara, dokumentasi, dan pretest-posttest kemampuan membaca permulaan secara tulis maupun lisan.

Uji validitas digunakan untuk mengukur kevalidan suatu instrumen penelitian. Dalam hal ini adalah RPP dan angket soal pretest/posttest tes lisan dan tulis. Instrumen divalidasi sebelum dibagikan kepada responden. Construct validity dilakukan oleh validator ahli untuk dikontruksi tentang aspek format, aspek bahasa, dan aspek isi. Validitas angket dilakukan dengan memberi skor sesuai likert yang bertujuan untuk mengukur kesesuaian pernyataan angket dengan indikator variabel. Hasil uji validitas angket kemampuan membaca permulaan siswa yang dilakukan oleh validator ahli terdapat skor 4 dengan rata-rata 4 dan catatan angket kemampuan membaca permulaan siswa sudah dapat digunakan dalam penelitian. Dari hasil uji validitas tersebut, dapat disimpulkan bahwa angket kemampuan membaca permulaan siswa layak digunakan dan disebarkan kepada responden. Selain itu, untuk menentukan kategori kemampuan membaca permulaan siswa yang diambil dari nilai pretest dan posttest dapat dilihat pada tabel berikut.

Tabel 1 kriteria kualifikasi kemampuan siswa

\begin{tabular}{ccc}
\hline No. & Kriteria & Keterangan \\
\hline 1. & $85-100$ & Sangat baik \\
\hline 2. & $70-84$ & Baik \\
\hline 3. & $55-69$ & Cukup \\
\hline 4. & $46-54$ & Kurang \\
\hline 5. & $0-45$ & Sangat kurang \\
\hline
\end{tabular}

Analisis data menggunakan Uji prasyarat analisis untuk menentukan kedua sampel yaitu uji normalitas dan homogenitas menggunkan spss 16.0. hal ini dilakukan untuk mengetahui sampel apakah normal dan homogen. Jika kedua sampel tersebut normal dan homogen maka menggunakan uji t regresi sederhana. Hal ini 
3146 Pengaruh Penerapan Metode SAS (Struktural Analitik Sintetik) terhadap Kemampuan Membaca Permulaan Siswa di Sekolah Dasar-Afifatus Silfiyah, Syamsul Ghufron, Muslimin Ibrahim, Pance Mariat

DOI: https://doi.org/10.31004/basicedu.v5i5.1321

untuk mengetahui ada tidaknya pengaruh penerapan metode SAS. Kategori penerimaan hipotesis yaitu: jika signifikansi $\geq 0,05$ maka $\mathrm{H}_{\mathrm{o}}$ diterima, jika signifikansi $<0,05$ maka $\mathrm{H}_{1}$ ditolak.

\section{HASIL DAN PEMBAHASAN}

Penelitian ini meliputi beberapa tahapan, yakni pre-test dan posttest, tahapan semua siswa dikasih pretest kemudian pada kelas eksperimen diberikan perlakuan berupa metode SAS (Struktural Analitik Sintetik) dan tahapan yang terakhir yaitu diberikan posttest.

Sampel penelitian ini adalah kelas I Berikut ini hasil pretetest-posttest yang dilakukan pada kelas I UPT SD Negeri 266 Gresik adalah sebagai berikut:

\begin{tabular}{ccccrr}
\hline \multicolumn{5}{c}{ Descriptive Statistics } \\
\hline & $\mathrm{N}$ & $\begin{array}{c}\text { Minim } \\
\text { um }\end{array}$ & $\begin{array}{c}\text { Maxi } \\
\text { mum }\end{array}$ & \multicolumn{1}{c}{ ean } & $\begin{array}{c}\text { Std. } \\
\text { Deviation }\end{array}$ \\
\hline $\begin{array}{c}\text { Pretest } \\
\text { Eksperimen }\end{array}$ & 24 & 36.66 & 73.33 & $\begin{array}{r}53 \\
.6075\end{array}$ & 9.57663 \\
\hline $\begin{array}{c}\text { Posttest } \\
\text { Eksperimen }\end{array}$ & 24 & 75.33 & 92.66 & 892 & 4.93722 \\
\hline Valid N (listwise) & 24 & & & &
\end{tabular}

Berdasarkan data di atas tes kemampuan membaca permulaan bahwa kenaikan nilai pre-test dan posttest kelas eksperimen yang mendapatkan perlakuan menggunakan metode SAS jauh lebih tinggi dibandingkan kelas sebelumnya sebelum menggunakan perlakuan. Pada kelas pre-test semula rata-rata adalah 53,60 kemudian pada saat kelas posttest naik menjadi 82,99

Kemudian untuk mengetahui perbedaan antara pretest dan posttest maka harus melakukan uji hipotesis atau pengambilan keputusan. Dalam menentukan keputusan maka dibutuhkan uji prasyarat. Uji prasyarat dalam penentuan analisis ini meliputi uji normalitas dan homogenitas,berikut ini hasil uji prasyarat analisis hasil normalitas dan homogenitas pretest-posttest.

Tabel hasil uji normalitas

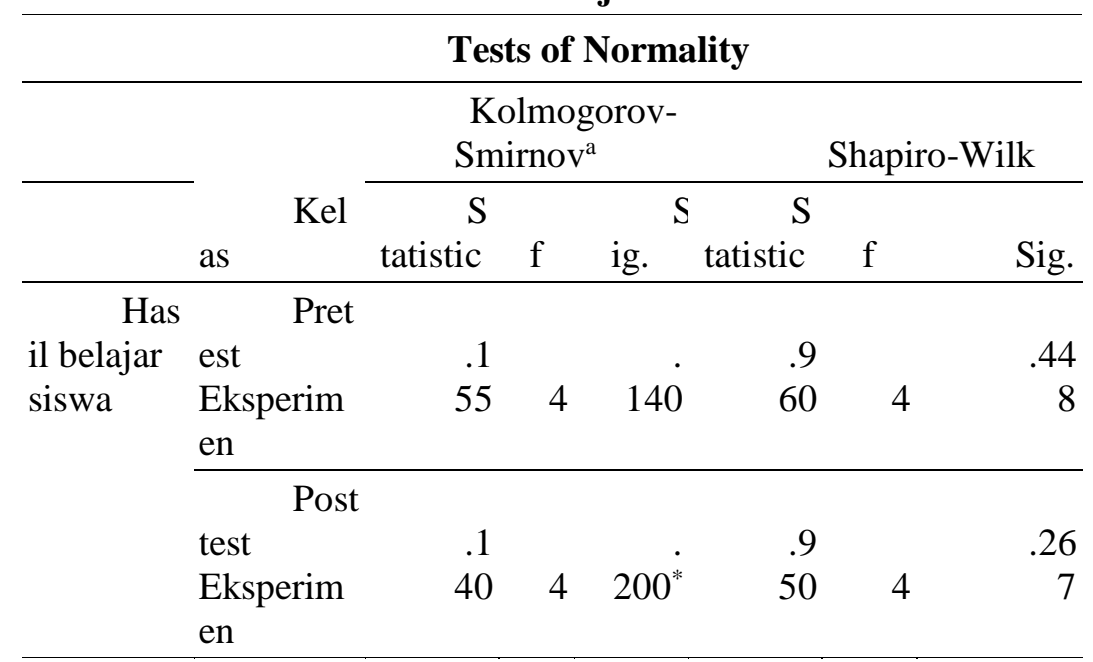

Significance

a. Lilliefors

Correction

*. This is a lower bound

of the true significance. 
3147 Pengaruh Penerapan Metode SAS (Struktural Analitik Sintetik) terhadap Kemampuan Membaca Permulaan Siswa di Sekolah Dasar-Afifatus Silfiyah, Syamsul Ghufron, Muslimin Ibrahim, Pance Mariat

DOI: https://doi.org/10.31004/basicedu.v5i5.1321

Tabel hasil uji homogenitas

\begin{tabular}{|c|c|c|c|c|c|}
\hline \multicolumn{6}{|c|}{ Test of Homogeneity of Variance } \\
\hline & & \multicolumn{2}{|l|}{ Lev } & \multirow[b]{2}{*}{ df } & \multirow[b]{2}{*}{ S } \\
\hline & & ene & & & \\
\hline & & Statistic & f1 & 2 & ig. \\
\hline \multirow{8}{*}{$\begin{array}{c}\text { Hasil } \\
\text { belajar siswa }\end{array}$} & Based on Mean & 7.3 & & 16 & \\
\hline & & 76 & & 40 & 009 \\
\hline & Based on Median & $7 .($ & & 46 & \\
\hline & & 12 & & 40 & 011 \\
\hline & Based on Median & 7.0 & & 33 & \\
\hline & and with adjusted df & 14 & & .286 & 012 \\
\hline & Based on trimmed & 7.3 & & & \\
\hline & mean & 73 & & 46 & 009 \\
\hline
\end{tabular}

Berdasarkan tabel diatas hasil uji normalitas pretest-posttest memiliki nilai sig. $>0,05$. Hasil perhitungan skor pretest diketahui nilai sig sebesar 0,448 sedangkan pada kelas posttest diketahui nilai sig. Sebesar 0,267 keduanya lebih besar dari 0,05. Maka dapat disimpulkan kedua hasil prestest-posttest berdistrubsi normal. Kemudian perhitungan pretest uji homogenitas kemampuan membaca permulaan sebesar 0,011, dan pada hasil posttest sebesar 0,09 nilai tersebut lebih besar dari nilai sig <0,05 sehingga kedua kelas tersebut dikatakan homogen.

Setelah dilakukan uji prasyarat analisis yakni uji normalita dan uji homogenitas diketahui kedua data tersebut normal dan homogeny langkah selanjutnya yakni melakuan uji $t$ melalui software SPSS 16.0. Penelitian ini menggunakan komparasi dua sampel independen (tidak berkorelasi). Uji $t$ digunakan untuk mengetahui apakah terdapat perbedaan rata-rata statistik antara kelas eksperimen dan kelas control setelah diberikan perlakuan. Berikut ini hasil uji $t$ dua pihak sampel independen,

Hipotesis yang diajukan dalam pengujian ini adalah sebagai berikut:

$\mathrm{H}_{0}=$ Tidak ada pengaruh metode struktur analitik sintetik terhadap rata-rata kemampuan membaca permulaan.

$\mathrm{H}_{1}=$ Terdapat pengaruh metode struktur analitik sintetik terhadap kemampuan membaca permulaan.

Berikut ini hasil uji t regresi sederhana:

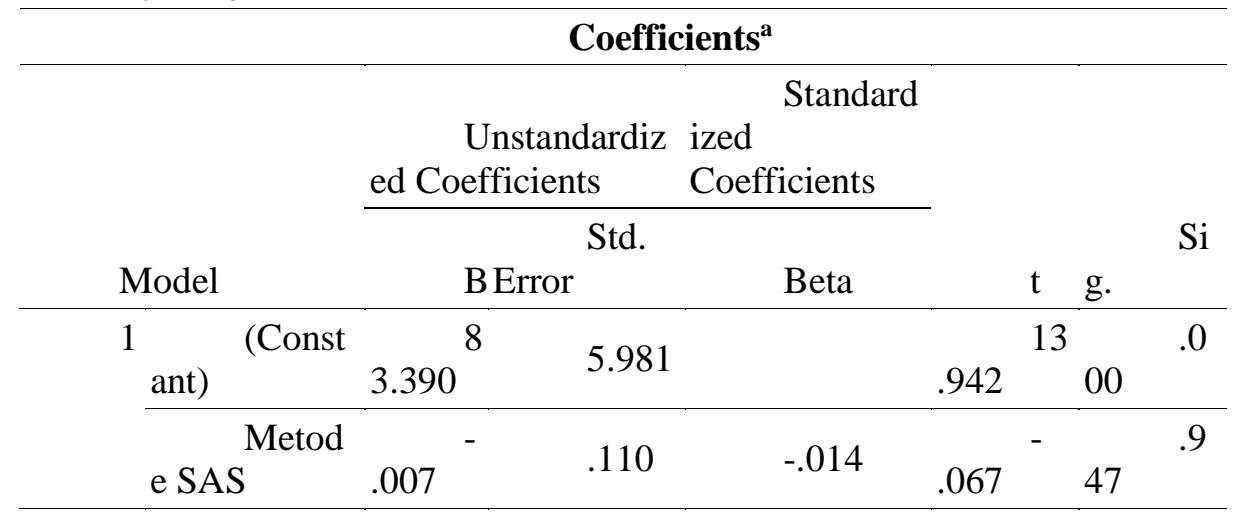

a. Dependent Variable: Kemampuan Membaca

Permulaan

Pengujian hipotesis metode SAS terhadap kemampuan membaca berdasarkan tabel diatas dapat diketahui nilai t hitung sebesar 13,942. Tabel distribusi dicari dengan tingkat signifikansi 0,05 maka diperoleh $\mathrm{t}$ tabel sebesar 2,069. Kriteria pengujian jika $\mathrm{t}$ hitung $\leq \mathrm{t}$ tabel maka $\mathrm{H} 1$ diterima, jika $\mathrm{t}$ hitung $>\mathrm{t}$ tabel maka Ho ditolak. Sehingga dapat diketahui bahwa 13,942>2,069, maka Ho ditolak dan H1 diterima. Berdasarkan 
3148 Pengaruh Penerapan Metode SAS (Struktural Analitik Sintetik) terhadap Kemampuan Membaca Permulaan Siswa di Sekolah Dasar-Afifatus Silfiyah, Syamsul Ghufron, Muslimin Ibrahim, Pance Mariat

DOI: https://doi.org/10.31004/basicedu.v5i5.1321

hasil pengujian hipotesis tersebut tersebut dapat disimpulkan bahwa hipotesis yang menyatakan "Ada pengaruh yang signifikan metode SAS terhadap kemampuan membaca siswa kelas I" terbukti , atau Hipotesis (H1) diterima. Artinya temuan tersebut membuktikan bahwa melalui metode SAS akan mampu mempengaruhi kemampuan membaca siswa kelas I.

Penggunanaan metode SAS (Struktrur Analitik Sintetik) juga sesuai dengan landasan pedagogis meliputi:

(1) mendidik adalah membantu siswa untuk mengembangkan potensi yang ada dalam dirinya serta pengalamannya. (2) membimbing murid untuk menemukan jawaban dalam memecahkan masalah. Hal ini sejalan dengan prinsip metode SAS yang mengemukakan bahwa mendidik pada dasarnya mengorganisasikan potensi dan pengalaman siswa.

\section{KESIMPULAN}

Berdasarkan uraian pembahasan di atas ditarik kesimpulan bahwa keterlaksanaan pembelajaran metode SAS Pada Pembelajaran membaca permulaan ini sudah terlaksana dengan baik.

Kemampuan membaca permulaan pada kelas I sebelum menerapkan metode SAS tergolong kurang, hal ini terbukti dari nilai rata-rata 53,575 hal ini juga dapat diketahui dari hasil membaca siswa yang intonasi suara, kelancaran membaca dan ketepatan lafal yang masih kurang.

Kemampuan membaca permulaan pada kelas I dengan menerapkan metode SAS tergolong baik, hal ini terbukti dari nilai rata-rata 82,97.hal ini juga dapat diketahui bahwa hasil membaca siswa yang sudah bagus mulai dari intonasi suara, kelancaran membaca dan ketepatan lafal yang sudah bagus.

Terdapat pengaruh penerapan metode SAS terhadap membaca permulaan siswa kelas I. Hal ini didasarkan pada hasil uji-t menyatakan bahwa nilai $t_{\text {hitung }}$ sebanyak $t_{\text {tabel }} 19,492>t_{\text {tabel }} 2,069$. Ini berarti nilai pretest berbeda dari nilai posttest. Dan nilai rata-rata posttest lebih baik daripada nilai rata-rata pretest.

\section{DAFTAR PUSTAKA}

Agnesta, D. L. (2019). Penerapan Metode Sas (Struktural Analitik Sintetik) Untuk Meningkatkan Keterampilan Menulis Tegak Bersambung Siswa Kelas Ii Sekolah Dasar. Journal Of Chemical Information And Modeling, 53(9), 1689-1699.

Broto. (2017). Metode Sas (Struktural Analitik Sintetik) Dalam Pembelajaran. Bulan Bintang.

Ghufron, S., Imroatun, R., Nahdlatul, U., Surabaya, U., Sugio, S. M. P. N., Islam, U., \& Ulum, D. (2020). Pembelajaran Menulis Teks Narasi Berdasarkan Teks Wawanacara Melalui Pendekatan Paikem. 20(2), 89-101. Http://Journal.Um-Surabaya.Ac.Id/Index.Php/Didaktis/Article/View/4506/2821

Laely, K. (2013). Melalui Penerapan Media Kartu Gambar Paud Pps Universitas Negeri Jakarta Kalinegoro Dengan Cara Dipaksakan Yaitu Anak. Pendidikan, 7(2).

Linda, P. K. (2014). Pengaruh Metode Sas Terhadap Hasil Belajar Mata Pelajaran Bahasa Indonesia. Vol.2,No.1.

Lisnawati, L., \& Muthmainah, M. (2018). Efektivitas Metode Sas (Struktur Analitik Sintetik) Dalam Meningkatkan Keterampilan Membaca Bagi Anak Lambat Belajar (Slow Learner) Di Sdn Demangan. Jurnal Psikologi Integratif, 6(1), 81. Https://Doi.Org/10.14421/Jpsi.V6i1.1468

Marlina. (2014). Meningkatkan Kemampuan Membaca Dengan Menggunakan Metode Sas Siswa Kelas I Sdn Ambunu Kecamatan Bungku Barat Kabupaten Morowali. 2(1), 15-27. 
3149 Pengaruh Penerapan Metode SAS (Struktural Analitik Sintetik) terhadap Kemampuan Membaca Permulaan Siswa di Sekolah Dasar-Afifatus Silfiyah, Syamsul Ghufron, Muslimin Ibrahim, Pance Mariat

DOI: https://doi.org/10.31004/basicedu.v5i5.1321

Muhyidin, A. (2019). Evaluasi Pembelajaran Membaca Permulaan Di Kelas Awal Sekolah Dasar. Rabit: Jurnal Teknologi Dan Sistem Informasi Univrab, 1(1), 2019.

Siregar, S. (2003). Metode Penelitian Kuantitatif: Dilengkapi Perbandingan Perhitungan Manual Dan Spss. Jakarta: Kencana Persada Media Group.

Soekarjo, D. M. (2004). Metodologi Penelitian Pendidikan. 160.

Sugiyono. (2016). Metode Penelitian Kuantitatif Kualitatif Dan R\&D. Bandung: Alfabeta.

Sunendar, I. Dan Dadang. (2015). No Title. In Strategi Pembelajaran Bahasa. Bandung: Pt. Rosdakarya.

Wahidah. (2016). Pengaruh Media Kartu Kata Terhadap Keterampilan Membaca Permulaan Bahasa Indonesia Siswa Kelas I Sd Inpres 6/57 Libueng Kecamatan Tonra Kabupaten Bone. Jakarta: Pt. Raja Grafindo Prasada. 